\title{
The Influence of Summative Evaluation on Classroom Practices in Rarieda Sub-County, Kenya
}

\author{
${ }^{* 1}$ Michael Olela, ${ }^{2}$ Prof. Daniel Allida, PhD and ${ }^{3}$ Prof. Elizabeth M. Role, PhD \\ ${ }^{1}$ Graduate Student, University of Eastern Africa, Baraton, Kenya \\ ${ }^{2}$ Professor of Education, Northern Caribbean University, Jamaica \\ ${ }^{3}$ Professor of Mathematics Education and Research Consultant, USA
}

*Corresponding Mail: michaelolela@yahoo.com

\begin{abstract}
This study investigated the perceptions on summative evaluation and its influences on the teachers' classroom practices among secondary schools in Rarieda Sub-county in Kenya. The study was guided by the extrinsic and intrinsic motivational theories. It employed the descriptive and correlational research designs. Stratified and simple random sampling techniques were used to obtain the sample of 250 teachers who participated in the stud through questionnaire and focus group discussion. Data was analyzed descriptively, thematically and through Pearson Correlations. The study revealed that the teachers had positive perceptions of both the classroom summative evaluation and national examination. In addition, the study established that there is significant relationship between perceptions on classroom summative evaluation and classroom management ( $r=.264)$, formative assessment $(r=.383)$ and syllabus completion $(r=.192)$ and between perceptions on national examination and lesson preparation $(r=.281)$, lesson implementation (lowerorder/higher-order) ( $r=.183)$, ( $r=.281)$, classroom management ( $r=.451)$ and formative assessment ( $r=.541)$. The study recommended that teachers should give their focus to students' acquisition of attitudes, values and skills that are needful in this century. They should also adopt good classroom practices to ensure in-depth learning.
\end{abstract}

Keywords: Assessment, classroom management, formative evaluation, summative evaluation

\section{Introduction}

Education has occupied an integral position in societies since time immemorial. This is because of its focus on the promotion of the full and wellrounded development of the physical, intellectual, social, affective, moral and spiritual qualities of learners so that they can develop into complete persons, for their own personal fulfillment and the good of the society (Kelly, 2009). However, quality is one of the crucial condiments that season the whole pedagogical process just as Digolo (2006) points out that society can only be nurtured through provision of not only accessible and relevant but also quality education. Therefore, quality education is a prerequisite to the attainment of both individual and national goals (Bunyi, 2013).

Kafwa, Mwaka and Musamas (2014) observed that proper evaluation tool that is used to monitor learning and measure the student's specific learning objective attainment is at the heart of quality education. MOEST (2015) has it that provision of quality education requires an effective quality assessment mechanism so as to ensure that the competencies spelt out in the curriculum are attained. Assessments that measure actual learner's competencies are an effective method of evaluating education systems across the world. Qu and Zhang (2013) likens it to a mirror because of its timely feedback on teaching and learning thereby enabling teachers and students to see the achievements and the gaps clearly and therefore to improve teaching and learning efficiently. Whether it be weekly test, end of term examination, terminal test, joint examination or national examination administered at the end of a course of study, its contribution remain significant in shaping the quality of education.

Many education systems across the globe have therefore adopted standardized tests as a means of assessment in education. Nichols and Berliner (2007) remark that examinations have been used the world over to assess students' aptitude and 
achievements in order to inform decisions about curriculum and instruction and to make predictions on how successful a student may be in the future.

However, the quality of education has somewhat been diluted by the overemphasis that has been put on examinations as teachers passionately seek the incentives that come with a good mean in the national examination as well as at the end-of-term while at the same time striving to evade the penalty meted out on those who have not added value on the students' attainments (Nichols \& Berliner, 2007). This has further been aggravated by the hard fact that the same learning achievement score determines the students' future life as it controls their placement in various courses at the next level of education and subsequent opportunities in life (Peacocks, 2011 as cited by Henry, Nyaga, \& Oundo, 2014).

Boit, Ann and Chang'ach (2012) reason out that learning has been condensed to studying the text especially at secondary school level because the most immediate and pressing goal is to pass tests as a master key to the academic/professional golden doors. In fact, the same mindset has infiltrated the institutions of learning as their success is determined by the passing score on the examinations (Ornstein \& Hunkins, 2009). Because of this problem, whatever is not examined or has never been the focus of the examiners is not prioritized (Hedwick, Mavies, Madungwe, \& Mandiudza, 2013). Thus, teaching becomes focused on what is needed to pass the test.

It is interesting to notice that this is not a unique phenomenon to Kenyan system alone. According to Rehmani (2003), research that was conducted in Pakistan revealed that teachers are bound to switch their teaching methods to mainly lecture methods while adopting teacher and curriculum centered approaches to teaching and learning in order to realize good performance in examinations. In the United States of America, Brink (2011) stated that standardized tests under the No Child Left Behind program have motivated teachers to change their instructional practices to those that would ensure better school performance in test results.

In America, Nichols and Berliner (2007) argued that high-stakes testing has tragically affected lives of individuals as some administrators and school boards have drastically narrowed the curriculum and forced test preparation programs on teachers and students, taking scarce time from genuine instruction. Hedwick et al. (2013) laments that even in Zimbabwe, education is almost synonymous with passing an examination. There is thus a discrepancy between the examination and curriculum aims (Hedwick et al., 2013). While examinations do not and actually cannot address all the knowledge, skills and attitudes spelled out in the curriculum to be developed in the learner, care should be taken so that curriculum aims are not replaced with the examination aims.

A report by UWEZO (2010) revealed a puzzlingly low learning achievement in schools in Kenya. According to the report, one out of ten pupils in class six could not read a textbook for class two. Although this was a research conducted in primary school, it may be the same unfortunate state of affair in the secondary schools as well because a survey results by the Kenya National Examinations Council (KNEC) released in February 2017 has also shown low achievement level of learners coupled with failure of teachers to manage learning accordingly (Mungai \& Psirmoi, 2018). Despite the measures put in place by the Teachers Service Commission (TSC) - Kenya, to ensure quality, including the introduction of the Teacher Performance Appraisal and Development Tool (TPAD) to guide curriculum implementation by assessing teacher accountability while at the same time seeking to subvert the influence of the teaching to the test, complaints have still emerged from leaders of political and religious spheres. Lecturers and even parents raise concerns about the ability of education and training to raise reliable and dependable citizens. This situation led researchers in this study to come up by the following research questions:

1. What are the teachers' perceptions on the role of classroom summative evaluations and national examination toward the attainment of learning objectives?

2. Is there a significant relationship between the teachers' perceptions on (a) the role of classroom summative evaluations and (b) national examination and the following variables?
a. Lesson preparation
b. Lesson implementation
c. Classroom management
d. Formative assessments
e. Syllabus completion

\section{Theoretical Framework}

This study was guided by two streams of social science theories of motivation - extrinsic and 
intrinsic - which expound on the possible root cause of the teacher perception on the summative evaluation and how it influences teachers' practice. This is premised on Hanushek and Rivkin's belief that good teachers enhance student learning (Hanushek \& Rivkin, 2010). According to Firestone (2014), the former theory is grounded on economics and relies heavily on extrinsic incentives to motivate educators. It is what the researcher can refer to as "carrot and stick" approach. It recommends the use of qualitative data to distribute rewards and punishment. It also advocates removal of "bad teachers," using differential rewards to improve teaching. The shortcoming of this theory is that it monitors the outcome but does not give attention to the action that could have led to it. This provides a loophole in the instructional process that is supposed to be a systematic undertaking. The teachers are thus free to choose what methods, content and procedures to reach the target without necessarily considering the laid down procedures. The educational systems operating under the principles of this theory can easily condition its teachers to perceive the role of summative evaluation to be production of "good" results per se and not as an important guide to the learning process. Subsequently, that would influence how they hold and understand the place of lesson preparation and implementation, classroom management practices, formative assessment and completion of the syllabus as the teachers would seek a shortcut route to effectively "manufacture" grades. This can deepen further the disconnection between theory and practice of education such that the newly trained teachers have to learn new survival tricks in the field after being deployed.

The second theory (intrinsic motivation) is based on psychology and it stresses intrinsic incentives. It advocates for improvement of the current teachers through capacity building using training and professional development. This theory involves motivation of the teachers by providing them with the tools they need to succeed. Intrinsic motivation is self-motivation. Firestone (2014) while citing Deci and Ryan (1996) explains that such persons reward themselves as a response to the feedback they receive from their work; they feel good when they do certain things. Portia (2017) adds that such persons work hard and are extremely focused on their work and their goal is to do the work right. They experience both autonomy and self-efficacy and they don't need any additional incentive because they find the activity itself interesting and fulfilling (Firestone, 2014). Such kind of teachers would work tirelessly to dispense the syllabus content using the best methodology and at all times seek to make learning as interesting and exciting as possible because their main focus is not the flaunted gifts but learning. They may be seen as slow in completing the syllabus and the students may severely complain when they compare the quantity of their covered work with other student. However, their students receive firm foundations which spur them to altitudinous heights with all required skills.

\section{Research Methodology}

This section presents the research methodology that was employed in this study.

\section{Research Design}

This study utilized a combination of descriptive and correlational research designs. The descriptive design is quite often preferred in exploratory studies to enable researchers not only to explain what exists in a given population at a particular time (Mugenda \& Mugenda, 2003; Role, 2017) but also to gather information, summarize it, present it and interpret it (Orodho, 2008). Correlational design, on the other hand, which according to Role (2017) explores the degree of relationship between two or more variables, was suitable in determining the relationship between the teachers' perceptions on summative evaluation and selected dependent variables.

\section{Population and Sampling}

According to the Teachers Service Commissions staffing record in Rarieda sub-county, the study's population was 960 teachers employed by the Teachers Service Commission (TSC) and those serving under the Board of Management in 41 public secondary schools across Rarieda Sub-county. The researchers stratified the schools into girls,' boys,' and mixed. This sub-county consists of two boys' schools, four girl's schools and thirty-five mixed schools. The researchers involved the two boys' and four girls' schools and randomly sampled 12 out of 35 mixed schools then involved all the teachers in the 18 schools whose total was 250 . The teachers were found useful because they deal with curriculum implementation and therefore their perception on summative evaluation is likely to influence the attainment of learning objectives.

\section{Instruments and Data Collection}

Questionnaire and focus group discussion were used to gather data on teachers' perceptions on

\section{East African Journal of Education and Social Sciences (EAJESS) 2(3)69-78}


summative evaluation and its influence on teachers' classroom practices. The questionnaire was chosen because the respondents were literate and therefore able to read and respond to the items. Moreover, the respondents were able to answer closed-ended questions in the questionnaire more easily and quickly and had greater confidence in their anonymity, thereby feeling free to express their views (Role, 2017). The focus group discussion was conducted with a selected group of six teachers from the schools to get in-depth information on some of the practices adopted by the individual teachers and schools to execute the curriculum demands.

\section{Validity and Reliability}

To ensure accuracy of the instruments, the questionnaire was subjected to research experts at the University of Eastern Africa, Baraton in Kenya for scrutiny. The experts gave comments for improvement prior to data collection. After the pilot study, a thorough examination for consistency and relevance of the instruments was done. The study ensured the acceptable reliability of the questionnaire by piloting it to 30 respondents drawn from 3 schools in the neighboring Bondo SubCounty in Siaya County. The data was then analyzed to determine the Cronbach's alpha value which should be above .60 (Cohen, Manion \& Morrison, 2007). The Cronbach's alpha .808 was obtained for the perception on the role of classroom summative evaluation, .727 for the perception on the role of national examination, .810 for lesson preparation, .649 for lesson implementation, .620 for classroom management, .719 for formative assessment and.683 for syllabus completion. Therefore, the instruments were fit for the actual data collection.

\section{Statistical Treatment of Data}

The data from the questionnaire and the focus group discussions was analyzed through descriptive statistics using mean scores and standard deviation in tables. Pearson Product-moment Correlation Coefficient was employed to establish the degree of relationship between the teacher's perception and the dependent variables.

\section{Ethical Considerations}

The investigators adhered to ethical standards required for research. Permission was obtained from the National Commission for Science, Technology and Innovation in Kenya (NACOSTI) as well as from the Sub-County Director of Education. The participants were informed of the purpose and significance of the study and the about the right to participate or withdraw from the study.

\section{Findings and Discussion}

This section presents the findings of the study, its analysis and interpretation, guided by the research questions. The analysis begins with presentation of demographic factors and then moves into the analysis of research questions.

Findings on Table 1 reveal that the respondents were blended in terms of gender with $68.8 \%$ being male while $31.3 \%$ being female. It also reveals a slight gender imbalance as majority of the teachers in the schools who responded were male while a few were female.

\begin{tabular}{lcc}
\multicolumn{3}{c}{ Table 1: Gender } \\
\hline GENDER & Frequency & Percent \\
\hline Male & 143 & 68.8 \\
Female & 65 & 31.3 \\
Total & $\mathbf{2 0 8}$ & $\mathbf{1 0 0 . 0}$ \\
\hline
\end{tabular}

As seen in Table 2, majority of the respondents had been practicing the teaching profession for a period of 1-5 years recording a percentage of 40.9 . This is an indication that a bigger percentage of the teachers have not had an extensive and advanced experience in teaching. However, the 19.2 percent representing the most experienced teachers would play a significant role of mentoring the younger members in the process of their growth.

Table 2: Teaching Experience

\begin{tabular}{lcc}
\hline \multicolumn{1}{c}{ Experience } & Frequency & Percent \\
\hline Below 1 year & 22 & 10.6 \\
1-5 years & 85 & 40.9 \\
6-10 years & 37 & 17.8 \\
11-15 years & 12 & 5.8 \\
16-20 years & 12 & 5.8 \\
Over 20 years & 40 & 19.2 \\
Total & $\mathbf{2 0 8}$ & $\mathbf{1 0 0 . 0}$ \\
\hline
\end{tabular}

Table 3: Description of Schools

\begin{tabular}{lcc}
\hline School Nature & Frequency & Percent \\
\hline Boys' school & 34 & 16.3 \\
Girls' School & 67 & 32.2 \\
Mixed School & 107 & 51.4 \\
Total & $\mathbf{2 0 8}$ & $\mathbf{1 0 0 . 0}$ \\
\hline
\end{tabular}

According to Table 3, the majority of teachers (51\%) were from mixed secondary schools which were the majority as compared to boys' and girls' schools. The mixed schools are spread almost in every village and are pocket friendly to the parents since the fees charged is moderate (Ngware, Onsomu, Muthaka and Manda (2006). 
Research question 1: What are the teachers' perceptions on classroom summative evaluations and national examinations?

This research question was analyzed descriptively through mean scores and standard deviations under the following interpretation of the mean scores: $1.00-1.49=$ Negative, $1.50-2.49=$ Tend to be negative, $2.50-3.49=$ Tend to be positive and $3.50-$ $4.00=$ Positive.

\section{Perceptions on Summative Evaluation}

The findings in table 4 show that the teachers rated themselves to have positive perception that the internal examination results enable the teacher get feedback on his/her objective attainment the period of learning with a self-rating mean of 3.73. Further, the teachers tended to believe that the internal examination results enhance competition among the learners and boost performance at a rating mean of 3.49. Furthermore, they believed that the internal examination results determine a class' score in relation to other classes at a mean of 3.25 and those assessments make students attentive in the classroom at a rating mean of 3.16. The teachers also believed in the ability of the internal examination to make students confident (prepare students) for their final examination, the rating mean standing at 3.52. In addition, they tended to believe that the internal examination feedback is useful in enhancing students' performance at the mean of 3.46 .

The table also reveals that while the teachers believed that the internal examinations are used to make appropriate decisions on teaching and learning with the mean of 3.33 , they also tended to believe that many internal examinations interfered with teaching and learning with the mean of 2.86 .

Table 4: Perceptions on Summative Evaluations

\begin{tabular}{lcc}
\multicolumn{1}{c}{ Item in the Questionnaire } & Mean & Std. Dev \\
\hline The internal examination results enable the teacher get feedback on his/her objective & 3.73 & .579 \\
attainment in a period of learning & & .846 \\
The internal examination results enhance competition among the learners and boost & 3.49 & .991 \\
performance & 3.25 & .972 \\
The internal examination results determine a class' score in relation to other classes & 3.16 & .786 \\
Assessment makes students attentive in the classroom & 3.52 & .767 \\
The internal examination results make students confident (prepare students) for their & 3.46 & 1.178 \\
final examination (KCSE) & 2.86 & .909 \\
The internal examination feedback is useful in enhancing students' performance. & 3.33 & 1.221 \\
Many internal exams interfere with teaching and learning. & & .3 .37 \\
The internal examinations are used make to decisions on teaching and learning. & $\mathbf{3 8 0 0 2}$ \\
*I desire my students to pass their internal exams to avoid scolding and questioning & 2.2674 \\
from the leaders. & & $\mathbf{3 . 2 5}$
\end{tabular}

*Negative statement - recoded in the computation of the overall mean

However, their response varied as signified by a higher value of standard deviation (1.178) which is likely to mean that some of them tended to believe that such interference exists while others believed otherwise.

The teachers tended to be negative toward that their desire of students passing the internal exams is to avoid scolding and questioning from the leaders, with the mean of 2.37. Having a standard deviation score of 1.221 gave an impression that even though the teachers tended to be negative about the scolding and questioning from the leaders concerning the students' score in the internal exams, to some it was a reality that could have made them to do anything possible to ensure that their students pass the internal examination. As observed by Abobo and Orodho (2014), teaching is guided by a variety of beliefs that the teacher holds to be true. Therefore, teacher's beliefs among other factors shape their perception on various elements and processes of curriculum implementation. It therefore follows that what the teachers perceive to be the role of the classroom summative evaluation is likely to influence their classroom practices which is most significant process in curriculum implementation.

Based on the assertion of Brink (2011), if the summative tests results are put into better use, they help the teacher to identify how best to move the learners to the next level so as to achieve their best potentials. Therefore, the mean of 3.73 indicating the rating of teachers that the internal examination results enable them to get feedback on their objectives attainment in the period of learning can 
lead us to conclude that the teachers in Rarieda subcounty have understood the classroom summative evaluation tests to be an incredible means of obtaining valuable feedback to the intricate process of learning.

From the focus group discussion with the teachers, it came out that the examination results analysis was done through a joint staff analysis and through the departmental approach. It is also important to note that the analysis of the results was diagnostically conducted to identify the gaps and challenges so that to come up with way-forwards. This is quite consistent with the finding from the questionnaire which revealed that the teachers believed that the results of internal examination are a useful source of feedback to their teaching.

\section{Perceptions on National Examinations}

It is evident from the findings of the study as shown in Table 5 with the mean scoring of 3.40 that the teachers rated themselves as tending to believe that the national examination gives them a feedback to better their content delivery. They also tended to believe that the national examinations motivate students to study more seriously, with the mean score of 3.33 , that quality grades in the subject(s) they teach in the national examination give them high chances of getting professional incentives e.g. promotion or reward, with the mean of 3.25 , that the national examination is an instrument to create a fair competition among students, schools and counties, with the mean of 2.73 and that having good scores in national examinations give students a good prestige, with the mean of 3.37.

However, they tended to be negative that the implementation of national examinations reveals justice in passing the students, with the mean of 2.39 .

On the other hand, they tended to believe that national examinations induce teachers to set higher standards, the mean of 3.14 .

Table 5: Perceptions on National Examinations

\begin{tabular}{|c|c|c|}
\hline Item in the Questionnaire & Mean & Std. Dev \\
\hline The national examination gives me a feedback to better my content delivery & 3.40 & .906 \\
\hline National examinations motivate students to study more seriously. & 3.33 & .853 \\
\hline $\begin{array}{l}\text { Quality grades in my subject in the national examination gives me high chances } \\
\text { of getting professional incentives e.g. promotion or reward }\end{array}$ & 3.25 & .964 \\
\hline $\begin{array}{l}\text { The national examination is an instrument to create a fair competition among } \\
\text { students, schools and counties. }\end{array}$ & 2.73 & 1.174 \\
\hline Having good scores in national examinations give students a good prestige. & 3.37 & .907 \\
\hline $\begin{array}{l}\text { The implementation of national examinations reveals justice in passing the } \\
\text { students. }\end{array}$ & 2.39 & 1.043 \\
\hline National examinations induce teachers to set higher standards. & 3.14 & .942 \\
\hline $\begin{array}{l}\text { National examinations stimulate teachers to increase their use of other } \\
\text { teaching strategies which they believe improve examination performance. }\end{array}$ & 3.39 & .921 \\
\hline $\begin{array}{l}\text { *National examinations pressure teachers to teach for the sake of the students } \\
\text { to pass the examinations. }\end{array}$ & 2.63 & 1.240 \\
\hline $\begin{array}{l}\text { Too much emphasis on passing the national examinations leaves out the } \\
\text { aspects of attitudes, values, and skills that produce a wholistic individual. }\end{array}$ & 3.43 & .958 \\
\hline Perceptions on National Examinations & 3.0788 & .47016 \\
\hline
\end{tabular}

*Negative statement - recoded in the computation of the overall mean

they also perceived that national examinations stimulate teachers to increase their use of other teaching strategies which they believe improve examination performance, with the mean of 3.39, that national examinations pressure teachers to teach for the sake of the students to pass the examinations, with the mean of 2.63 and that too much emphasis on passing the national examinations leaves out the aspects of attitudes, values, and skills that are aimed to produce a wholistic individual, with the mean of 3.43.
It is important to note that from the findings of the study, the teachers of Rarieda sub-county tended to have a positive attitude towards the national examination since a number of them represented by the highest mean scores of 3.43 and 3.40 tended to believe that too much emphasis on passing the national examinations leaves out the aspects of attitudes, values, and skills that produce a wholistic individual and that national examination gives them a feedback to better the content delivery. This pointed out that these teachers are cautious about leaving out aspects of values, skills and attitudes 
and also they get to improve their teaching based on the results obtained from the national examination.

It is also revealed that the teachers pursued good mean and quality grades for professional incentives and prestige. They also employed some strategies to improve performance in the examination. In addition, some teachers tended to believe that the examinations create fair competition and pressurize teachers to teach for the sake of students' passing. This could suggest that some teachers were ready to do whatever it takes to ensure high mean and good grade of their students in the examination.

It is important to note that the national examination is held in such a high esteem in Kenya that the teachers, parents, students and other school stakeholders would do anything within their powers to determine a good grade (Jepkemoi, 2017) and so it is likely to affect the teachers' practice. The rating with the highest mean scores which revealed that teachers believed that much emphasis on passing the national examinations leaves out the aspects of attitudes, values and skills that produce a wholistic individual (3.43) is closely followed by the belief that the national examination gives them a feedback to better content delivery (3.40). This implies that these teachers may be least tempted to device ways of attaining good performance in the national examination which may include sacrificing for the betterment of the learners as advised by Ornstein and Hunkins (2009). It is also worth noting that the teachers believed that national examinations stimulate them to increase the use of various teaching strategies which they believed can improve the examination performance and that quality grades in the national examination for the subjects they teach gives them high chances of getting professional incentives such promotion or reward.

Research Question 2: Is there a significant relationship between (a) teachers' perception on the role of classroom summative evaluations and (b) national examination with the following variables?
a. Lesson preparation
b. Lesson implementation
c. Classroom management
d. Formative assessments
e. Syllabus completion

Table 6 presents two correlation analyses. The correlation co-efficient ranges from -1 to +1 , with -1 indicating a perfect negative correlation, +1 a perfect positive correlation, and 0 indicating no correlation at all. The Sig. (2-tailed) is the p-value associated with the correlation showing whether it is significant or not.

\section{Summative Evaluation and Classroom Practices}

According to Table 6, classroom management $(r=.264)$, formative assessment $(r=.383)$ and syllabus completion ( $r=.192)$ are directly related to the perceptions on classroom summative evaluation and the relationship is statistically significant because the p-values .000, .000 and .006 respectively are less than $\alpha=.01$.

Table 6: Correlations between Summative Evaluations and National Examination and Classroom Practices

\begin{tabular}{|c|c|c|c|}
\hline & & Summative Evaluation & National Examinations \\
\hline \multirow[t]{3}{*}{ Lesson Preparation } & Pearson Correlation & .055 & $.281^{* *}$ \\
\hline & Sig. (2-tailed) & .430 & .000 \\
\hline & $\mathrm{N}$ & 208 & 208 \\
\hline \multirow{3}{*}{$\begin{array}{l}\text { Lesson Implementation (Lower- } \\
\text { order) }\end{array}$} & Pearson Correlation & .042 & $.183^{* *}$ \\
\hline & Sig. (2-tailed) & .550 & .008 \\
\hline & $\mathrm{N}$ & 208 & 208 \\
\hline \multirow{3}{*}{$\begin{array}{l}\text { Lesson Implementation (Higher- } \\
\text { order) }\end{array}$} & Pearson Correlation & -.025 & $.281^{* *}$ \\
\hline & Sig. (2-tailed) & .718 & .000 \\
\hline & $\mathrm{N}$ & 208 & 208 \\
\hline \multirow[t]{3}{*}{ Classroom Management } & Pearson Correlation & $.264^{* *}$ & $.451^{* *}$ \\
\hline & Sig. (2-tailed) & .000 & .000 \\
\hline & $\mathrm{N}$ & 208 & 208 \\
\hline \multirow[t]{3}{*}{ Formative Assessments } & Pearson Correlation & $.383^{* *}$ & $.541^{* *}$ \\
\hline & Sig. (2-tailed) & .000 & .000 \\
\hline & $\mathrm{N}$ & 208 & 208 \\
\hline \multirow[t]{3}{*}{ Syllabus Completion } & Pearson Correlation & $.192^{* *}$ & .126 \\
\hline & Sig. (2-tailed) & .006 & .069 \\
\hline & $\mathrm{N}$ & 208 & 208 \\
\hline
\end{tabular}

**. Correlation is significant at the 0.01 level (2-tailed). 
On the other hand, lesson preparation ( $r=.055)$, lesson implementation (lower-order) $(r=.042)$ and lesson implementation (higher-order) ( $r=-.025)$ have $p$-values of .430, .550, and .718, which are greater than the set significance level of .05, thus, they are not significantly related to classroom summative evaluation in secondary schools within Rarieda SubCounty.

Therefore, teachers who have positive perceptions on classroom summative evaluations tend to have better classroom management, formative assessments and syllabus completion practices. On the other hand, the teachers' perceptions on classroom summative evaluations do not influence their lesson preparation and lesson implementation practices. This affirms the assertion by different scholars on the power of examinations on curriculum implementation (Ornstein \& Hunkins, 2009, Akaranga \& Ongong, 2013, Brink, 2011). The right perception of the teachers towards examination is therefore important in the implementation of the curriculum since most of the teachers' classroom practices are dependent on it.

\section{National Examination and Teachers' Practices}

Based on the analysis on Table 6, lesson preparation $(r=.281)$, lesson implementation (lower-order) $(r=.183)$, lesson implementation (higher-order) $(r=.281)$, classroom management $(r=.451)$, and formative assessment $(r=.541)$ are directly related to perceptions on national examination, having $p$ values less than .01. However, there is no significant relationship between syllabus completion ( $r=.126)$ and perception of teachers on the national examination among the teachers of Rarieda Subcounty. This shows that teachers who have positive perceptions on national examinations tend to have better lesson preparation, lesson implementation, classroom management and formative assessments practices even though the teachers' perceptions on national examinations do not influence their syllabus completion practices.

It should be noted that one's perception has such a strong influence to his or her life orientation and the decisions made. This does not exempt teachers as Abobo and Orodho (2014) observed. The teachers' beliefs, attitude and feelings play a great role in shaping their choices in the process of curriculum implementation. These influences may vary depending on what the teacher either personally or collectively hold to be true. According to the findings above, it is true that a wrong perception on the role of national examination can be quite detrimental to the process of learning as it influences a number of teacher classroom practices.

\section{Conclusions and Recommendations}

This section presents the conclusions of the study and then presents the recommendations of the study.

\section{Conclusions}

On the basis of the findings of this study, the researchers reached the following conclusions with regards to the perception on summative evaluation and its influence on classroom practice in Rarieda Sub-county, Kenya.

Teachers of public secondary schools in Rarieda Subcounty had a positive perception of both the classroom summative evaluation and national examination and believed that they were useful in learning because the results enabled the teachers to get feedback that could be used to improve learning. This implies that the teachers used examinations for formative purposes to diagnose learning gaps then formulate remedial strategies to ensure improved learning through attainment of learning objectives.

It is also concluded that teachers who have positive perceptions on classroom summative evaluations tend to have better classroom management, formative assessments and syllabus completion practices. Moreover, teachers who have positive perceptions on national examinations tend to have better lesson preparation, lesson implementation, classroom management and formative assessments practices. This means that attainment of the learning objectives, which are dependent on good classroom practices, can only be realized when teachers have the right perception on the role of summative evaluation.

\section{Recommendations}

Since there is significant relationship between perceptions on the role of classroom summative evaluation and classroom management, formative assessment and syllabus completion and between perceptions on national examination and lesson preparation, lesson implementation, classroom management and formative assessment, the researchers came up with the following recommendations:

Teachers should adopt good learner-centered classroom management, formative assessment, syllabus completion and lesson implementation practices which will ensure in-depth learning in the 
classroom. Stakeholders, while keeping checks and balances by ensuring that the examinations are taken seriously and the results are improved, should be well informed not to take the examinations as the absolute yardstick for measure of teachers' success but instead intensify classroom supervision, management and formative evaluation.

\section{References}

Abobo, F. \& Orodho, J. (2014). Life skills education in Kenya: An assessment of the level of preparedness of teachers and school managers in implementing Life Skills Education in Trans- Nzoia District, Kenya. IOSR Journal of Humanities and Social Science,19(9), 32-44.

Akaranga, I., \& Ongong, J. (2013). The phenomenon of Examination Malpractice: An example of Nairobi and Kenyatta Universities. Journal of Education and Practice, 4(18), 87 - 96.

Boit, M., Ann, N. \& Chang'ach, J. (2012). The influence of examination on the stated curriculum goals. American International Journal of Contemporary Research, 2(2), 179-182.

Brink, C. (2011). A Historical Perspective of Testing and Assessment Including the Impact of Summative and Formative Assessment on Student Achievement (Unpublished Dissertations). University of Southern Mississippi, USA. Available on: https://aquila.usm.edu/dissertations/409.

Bunyi, G. (2013). The quest for quality education: The case of curriculum innovations in Kenya. European Journal of Training and Development, 37 (7), 678 - 691. Permanent link to this document: http://dx.doi.o rg/10.1108/EJTD-01-2013-0008.

Cohen, L., Manion, L. \& Morrison, K. (2007). Research Methods in Education. (6 ${ }^{\text {th }}$ ed.). New York: Taylor \& Francis e-Library

Digolo, O. (2006). The challenges of education in Kenya in the 21 Century. The Educator, A Journal of School of Education, (1)1, 40-77.

Firestone, A. (2014). Teacher evaluation policy and conflicting theories of motivation. Educational Researcher, 43(2), 100-107. Downloaded from: http://journals.sa gepub.c o m/doi/pdf/ 1 0.3102/00 13 $189 \times 14521864$.
Hanushek, A. \& Rivkin, G. (2010). Generalizations about using value-added measures of teacher quality. American Economic Review, 100, 267-271. Retrieved from: http://hanushek.stanford.edu/sites/default/ files/publications/Hanushek\%2BRivkin\%202 010\%20AER\%20100\%282\%29.pdf

Hedwick, C., Mavies, K., Madungwe, L. \& Mandiudza, L. (2013). The impact of examinations on the school curriculum: A Zimbabwean perspective. International Journal of Academic Research in Progressive Education and Development, 2(1), 65-74.

Henry, E., Nyaga, V. \& Oundo, M. (2014). Effects of examination oriented teaching on academic aspiration among Secondary School Students in Imenti South District, Kenya. International Journal for Innovation Education and Research, (2)5, 58-66. Available on: www.ijier.net.

Jepkemoi, E. (2017, April 5). Curriculum reform: Is it worth the trouble? Standard Digital.

Retrieved from: https://www.google.com /amp/s/www.standardmedia.co.ke/mobile/ amp/article/2001235123/curriculum-reform -is-I t-worth-the-trouble.

Kafwa, N. Mwaka, M. \& Musamas, J. (2014). The evaluation dilemma in Kenya Education System. International J. Soc. Sci. \& Education, 4(2), 326-338.

Kelly, A. (2009). The Curriculum: Theory and Practice. $\left(9^{\text {th }}\right.$ ed.), London: Sage Publications Limited.

Mugenda, O. \& Mugenda, A. (2003). Research Methods: Qualitative and Quantitative Approaches. Nairobi: Acts Press.

Mungai, A. \& Psirmoi, D. (2018, February 3). Report blames teacher laxity for poor education standards. Standard Digital. Retrieved from: https://www.standardmedia.co.ke/article/2 001268341/report-blames-teacher-laxityfor-poor-education-standards

Ngware, M., Onsomu, E., Muthaka, D., \& Manda, D. (2006). Improving access to secondary education in Kenya: what can be done? Equal Opportunities International, 25(7), 523-543. Available 
on: https://doi.org/10.1108/02610150610 714367

Nichols, D. \& Berliner, C. (2007). Collateral Damage: How High-Stakes Testing Corrupts American Schools. Cambridge, MA: Harvard Education Press.

Orodho, J. (2008). Techniques of Writing Research Proposals and Reports: In Education and Social Sciences. Maseno, Kenya; Kenzia Publishers.

Ornstein, A. \& Hunkins, F. (2009). Curriculum: Foundations, Principles and Issues. Boston, MA: Allyn and Bacon.

Portia, J. (2017). Teacher and Administrator Perceptions of the Effectiveness of a Teacher

Evaluation System and Its Impact on Student Learning. (Doctoral dissertation, Clark Atlanta University). Downloaded from: http://digitalcommons.auctr.edu/cauetds/8 0
Qu, W. \& Zhang, C. (2013). The analysis of summative assessment and formative assessment and their roles in college English assessment system. Journal of Language Teaching and Research, 4(2), 335-339.

Rehmani, A. (2003). Impact of Examination System on Teaching and Learning in Pakistan. Aga Khan University Examination Board.Retrieved from: https://www.acade mia. e du/2440300/

Role, E. (2017). Handbook of Educational Research Methods (Class handout). School of Education, Humanities and Social Sciences, University of Eastern Africa, Baraton, Kenya.

Uwezo (2010). Are our children learning: Annual learning assessment Kenya 2010. Women Educational Researchers of Kenya (WERK). Retrieved from: http:// www.uwezo.net/wpcontent/uploads/2012/ 08/KE_2010_AnnualAssessmentReportSum mary.pdf 